\title{
Life-threatening right atrial thrombus in a premature newborn successfully treated with recombinant tissue plasminogen activator
}

\author{
Wendy Dewals and Abraham Benatar* \\ Department of Paediatric Cardiology, Universitair Ziekenhuis (VUB), Vrije Universiteit Brussel (VUB), Brussels, Belgium
}

\begin{abstract}
Venous thrombosis is a known complication of indwelling central venous catheters in the Neonatal Intensive Care Unit population. Patients often present with little to no symptoms. Life-threatening intracardiac and great vessels thrombi are rare. Recombinant tissue plasminogen activator (rt-PA) is used in adults to stimulate fibrinolysis and facilitate thrombus resolution. Its use in neonates, along with heparin, remains controversial because of potential risk of serious bleeding. We report on a ten-day-old 1200-gram premature infant hemodynamically compromised from a large right atrial thrombus successfully treated with recombinant tissue plasminogen activator.
\end{abstract}

\section{Introduction}

Thrombi are mostly present in the hepatic vein, the inferior vena cava and the right atrium. The most frequent symptoms in case of right atrial thrombosis are arrhythmia, respiratory distress, sudden manifestation of murmur and signs of right-sided heart failure. Reports on fatal or life-threatening thrombi are relatively rare [1-6]. Treatment options for those acute life-threatening thrombi consist of antithrombotic therapy or surgical removal.

We report the successful use of recombinant tissue plasminogen activator in a premature baby born at 30 weeks gestational age.

\section{Case report}

A ten-day-old, premature girl, gestational age of 30 weeks and 6 days, and weight of $1,2 \mathrm{~kg}$ at birth, developed sepsis within 12 hours after removal of an umbilical vein catheter. Laboratory findings showed an important rise in inflammatory parameters as well as a strong suggestion of associated disseminated intravascular coagulopathy. A wide spectrum antibiotic therapy was administered whilst being mechanically ventilated. Via a peripheral approach a central line was inserted, with the tip of the catheter positioned at the superior vena cava-right atrial junction. Within 24 hours after onset of sepsis, acute desaturation arose. Increasing inspiratory oxygen concentration and optimisation of ventilatory settings did not adequately improve the saturation. Clinical examination revealed poor peripheral circulation, prolonged capillary refill, narrow pulse pressure and hepatomegaly. Additionally, the blood acid base and $\mathrm{pH}$ identified the presence of lactic acidosis with low $\mathrm{Pa}_{2}$. Transthoracic echocardiography revealed a giant mobile right atrial thrombus occupying nearly the entire right atrium (Figures $1 \mathrm{~A}$ and $1 \mathrm{~B}$ ), and prolapsing into the tricuspid valve. The blood flow through the tricuspid valve was obstructed, causing impaired filling of the right ventricle and compromising the circulation.

In the setting of a potentially lethal hemodynamic status, urgent thrombolysis was attempted with the use of recombinant tissue

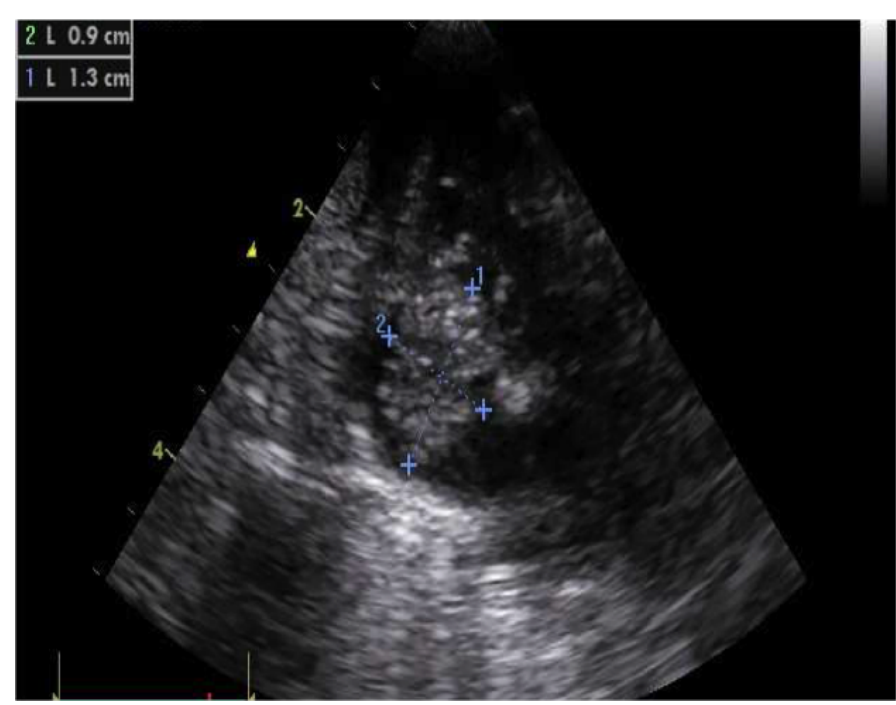

Figure 1A. A subcostal four chamber view of the heart showing the right atrium completely covered with thrombus (the crosses outline the dimensions).

plasminogen activator at a dose of $0,3 \mathrm{mg} / \mathrm{kg} / \mathrm{h}$ and concurrent fresh frozen plasma (FFP) during six hours [7]. Significant clinical improvement was observed within 3 hours of treatment initiation (rise in blood pressure, saturation and peripheral perfusion). A repeat

*Correspondence to: Abraham Benatar, Department of Paediatric Cardiology, Universitair Ziekenhuis (VUB), Laarbeeklaan 101, 1090 Brussels, Belgium, Tel: +3224776062; E-mail: Abraham.benatar@uzbrussel.be

Key words: premature, thrombosis, recombinant tissue plasminogen activator, coagulation, central catheter, very low birth weight, emboli

Received: January 27, 2018; Accepted: February 2, 2018; Published: February 26,2018 


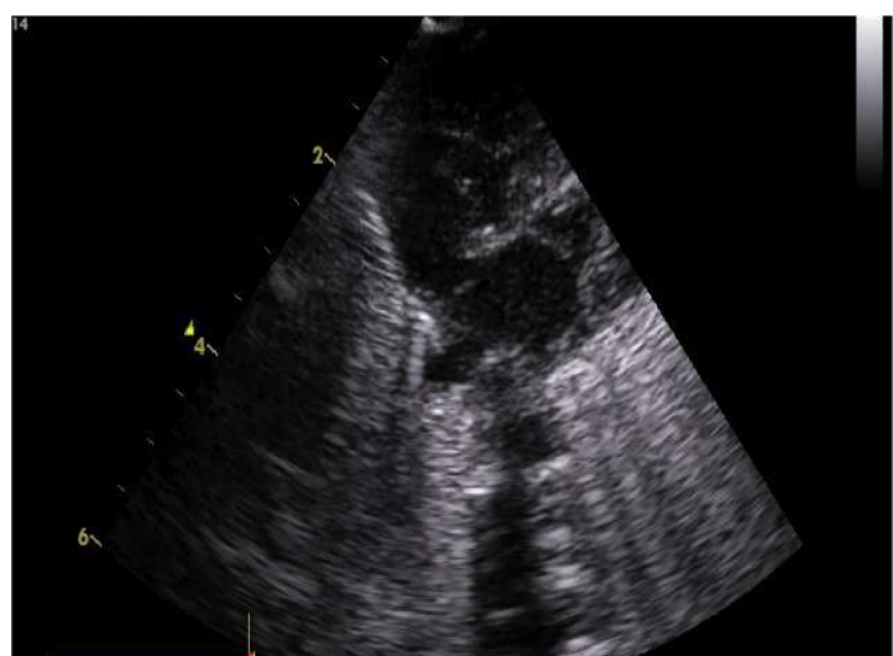

Figure 1B. A subcostal four chamber view of the heart showing the right atrium showing complete dissolution of the thrombus.

echocardiographic examination twelve hours after start of thrombolysis therapy showed almost complete dissolution of the thrombus.

Subsequent anticoagulation was continued with heparin during five days then switched to fractionated heparin from day 6 , for a total duration of six weeks. She developed no haemorrhagic complications, although a trans-fontanel ultrasound revealed a picture suggestive of paradoxical embolic events, probably due to emboli crossing a patent foramen ovale to the left heart. She was discharged in good clinical condition six weeks later.

\section{Discussion}

Right atrial thrombi are frequently reported, though most are asymptomatic [8-11]. Data on the treatment of life-threatening thrombi in newborns particularly premature infants are scarce, only a few reported [1-6,12].

Guidelines for the use of thrombolytic agents in adults are well established, whereas there is still uncertainty in paediatric treatment regimens, especially in neonates. The efficacy and safety profile of their use is limited due to a lack of controlled prospective studies. The current literature provides only sporadic case reports and small case series regarding thrombolytic agent use in infants and neonates [4,9,13-15]. Despite successful results in reported cases, the fear of serious bleeding and intracranial haemorrhage exists.

Anticoagulation in infants cannot be extrapolated from the adult regimens since the haemostasis system, thrombotic causes and pharmacokinetics of antithrombotic agents differ markedly in the newborn setting. Plasma concentrations of plasminogen in infants are much lower compared to adults, estimated as low as $50 \%$. Consequently, in vitro decrease of the thrombolytic effect of tissue plasminogen activator (tPA) is observed. Administration of fresh frozen plasma prior to the administration of rtPA augments the thrombolytic effect [7].

A right atrial thrombus in neonates, infants and children is usually seen in association with the presence of a central venous catheter. In our case, the predisposing factors of this major thrombotic event were premature birth, the presence of a central line and sepsis.

Therapeutic options for treatment of right atrial thrombosis consist of no treatment, heparinisation, thrombolysis or surgical removal. Since the thrombus in our patient had dire hemodynamic consequences, only the two last options were considered. On account of the sudden deterioration in hemodynamic status, and instability, surgical thrombectomy, with need of transfer to a surgical centre was considered of higher risk.

Thrombolytic therapy with recombinant tissue plasminogen activator is usually the preferred treatment as it has a short half-life, fewer systemic side effects, and a strong, specific affinity for fibrin. Protocols vary from centre to centre, but there is still no consensus regarding the proper dosage or treatment duration [7].

Attempted thrombolysis of the thrombus was considered the only lifesaving practical option, despite the known high haemorrhagic risks in premature infants. The use of rt-PA in this age group is generally contraindicated $[7,16]$. Several small studies and case series have been published, establishing the use of rt-PA in premature born neonates. There is however no clear consensus on dose and site of administration. Low dose administration of less than $0,1 \mathrm{mg} / \mathrm{kg} / \mathrm{h}$ was not considered an option because of the life-threatening event. We empirically used a dose of $0,3 \mathrm{mg} / \mathrm{kg} / \mathrm{h}$ without bolus with FFP given simultaneously with the administration of rt-PA on account of the emergency. A new central catheter was inserted and positioned at the entry of the right atrium, for the administration of the rt-PA close to the thrombus.

Echocardiographic follow up examination showed an almost complete resolution within a few hours after initiation of therapy.

In conclusion, this premature infant, with life-threatening right atrial thrombus compromising the cardiac output, responded favourably to rt-PA therapy. No side effects occurred from rt-PA administration at a dose of $0,3 \mathrm{mg} / \mathrm{kg} / \mathrm{h}$ during six hours, concurrent with FFP. The thrombus dissolved within a few hours after initiation of rt-PA.

\section{References}

1. Van Overmeire B, Van Reempts PJ, Van Acker KJ (1992) Intracardiac thrombus formation with rapidly progressive heart failure in the neonate: treatment with tissue type plasminogen activator. Arch Dis Child 67: 443-445. [Crossref]

2. Kalaniti K, Lo Rito M, Hickey EJ, Sivarajan VB (2015) Successful pulmonary embolectomy of a saddle pulmonary thromboembolism in a preterm neonate. Pediatrics 135: e1317-1320. [Crossref]

3. DeMeo SD, Sherwood A, Hornik CD, Goldberg RN, Cotten CM et al. (2014) Pulmonary artery thrombus in a premature neonate treated with recombinant tissue plasminogen activator. J Perinatol 34: 569-571. [Crossref]

4. Yang JY, Williams S, Brandão LR, Chan AK (2010) Neonatal and childhood righ atrial thrombosis: recognition and a risk-stratified treatment approach. Blood Coagul Fibrinolysis 21: 301-307. [Crossref]

5. Nowak-Gottl U, von Kries R, Gobel U (1997) Neonatal symptomatic thromboembolism in Germany: two year survey. Arch Dis Child Fetal Neonatal Ed 76: F163-167. [Crossref]

6. Ulubas ID, Celik IH, Yilmaz O, Bas AY, Demirel N (2016) A Previously Healthy Premature Infant Treated with Thrombolytic Therapy for Life-threatening Pulmonary Artery Thrombosis. J Pediatr Hematol Oncol 38: e319-e321. [Crossref]

7. Monagle P, Chan AKC, Goldenberg NA, Ichord RN, Journeycake JM, et al. (2012) Antithrombotic therapy in neonates and children: Antithrombotic Therapy and Prevention of Thrombosis, (9thedn), American College of Chest Physicians EvidenceBased Clinical Practice Guidelines. Chest 141: e737S-e801S. [Crossref]

8. van Elteren HA, Veldt HS, Te Pas AB, Roest AA, Smiers FJ, et al. (2011) Managemen and outcome in 32 neonates with thrombotic events. Int J Pediatr 2011: 217564. [Crossref]

9. Hartmann J, Hussein A, Trowitzsch E, Becker J, Hennecke KH (2001) Treatment of neonatal thrombus formation with recombinant tissue plasminogen activator: six years' experience and review of the literature. Arch Dis Child Fetal Neonatal Ed 85: F18-22. [Crossref]

10. Giuffre B, Compagnoni G, Farina C, Mosca F (1998) Successful use of tissue plasminogen activator (t-PA) in catheter-related intracardiac thrombi of two premature infants. Acta Paediatr 87: 695-698. [Crossref]

11. Baykan A, Ozyurt A, Korkmaz L, Pamukcu O, Argun M, et al. (2014) Giant right atrial thrombus in premature newborn. J Thromb Thrombolysis 37: 353-355. [Crossref] 
Dewals W (2018) Life-threatening right atrial thrombus in a premature newborn successfully treated with recombinant tissue plasminogen activator

12. Gamillscheg A, Nürnberg JH, Alexi-Meskishvili V, Werner H, Abdul-Kaliq H, et al. (1997) Surgical emergency embolectomy for the treatment of fulminant pulmonary embolism in a preterm infant. J Pediatr Surg 32: 1516-1518. [Crossref]

13. El-Segaier M, Khan MA, Khan ZU, Momenah T, Galal MO (2015) Recombinant Tissue Plasminogen Activator in the Treatment of Neonates with Intracardiac and Great Vessels Thrombosis. Pediatr Cardiol 36: 1582-1587. [Crossref]

14. Farnoux C, Camard O, Pinquier D, Hurtaud-Roux MF, Sebag G, et al. (1998) Recombinant tissue-type plasminogen activator therapy of thrombosis in 16 neonates. J Pediatr 133: 137-140. [Crossref]
15. Ferrari F, Vagnarelli F, Gargano G, Roversi MF, Biagioni O, et al. (2001) Early intracardiac thrombosis in preterm infants and thrombolysis with recombinant tissue type plasminogen activator. Arch Dis Child Fetal Neonatal Ed 85: F66-69. [Crossref]

16. Manco-Johnson MJ, Grabowski EF, Hellgreen M, Kemahli AS, Massicotte MP, et al. (2002) Recommendations for tPA thrombolysis in children. On behalf of the Scientific Subcommittee on Perinatal and Pediatric Thrombosis of the Scientific and Standardization Committee of the International Society of Thrombosis and Haemostasis. Thromb Haemost 88:157-158. [Crossref]

Copyright: $\odot 2018$ Dewals W. This is an open-access article distributed under the terms of the Creative Commons Attribution License, which permits unrestricted use, distribution, and reproduction in any medium, provided the original author and source are credited. 